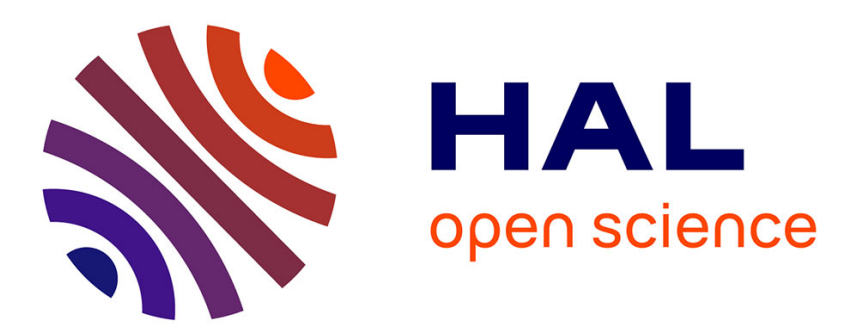

\title{
Hydromechanical behaviour of a compacted swelling soil over a wide suction range
}

Olivier Cuisinier, Farimah Masrouri

\section{To cite this version:}

Olivier Cuisinier, Farimah Masrouri. Hydromechanical behaviour of a compacted swelling soil over a wide suction range. Engineering Geology, 2005, 81 (3), pp.204 - 212. 10.1016/j.enggeo.2005.06.008 . hal-01768451

\section{HAL Id: hal-01768451 \\ https://hal.science/hal-01768451}

Submitted on 17 Apr 2018

HAL is a multi-disciplinary open access archive for the deposit and dissemination of scientific research documents, whether they are published or not. The documents may come from teaching and research institutions in France or abroad, or from public or private research centers.
L'archive ouverte pluridisciplinaire HAL, est destinée au dépôt et à la diffusion de documents scientifiques de niveau recherche, publiés ou non, émanant des établissements d'enseignement et de recherche français ou étrangers, des laboratoires publics ou privés. 


\section{HYDROMECHANICAL BEHAVIOUR OF A COMPACTED SWELLING SOIL OVER A WIDE SUCTION RANGE}

\section{Olivier CUISINIER \& Farimah MASROURI*}

Laboratoire Environnement Géomécanique \& Ouvrages

École Nationale Supérieure de Géologie

Institut National Polytechnique de Lorraine

Rue du Doyen Marcel Roubault, BP 40

54501 Vandœuvre-lès-Nancy

FRANCE

* Corresponding author

Phone: (+33) 383596304

Fax: (+33) 383596300

Farimah.Masrouri@ensg.inpl-nancy.fr 


\section{ABSTRACT:}

A study of the hydromechanical behaviour of a compacted swelling material in the range of suctions comprised between 0 and $40 \mathrm{MPa}$ was performed. This study has required the development of two kinds of suction controlled oedometer devices based on two different suction control techniques. In the range of suctions higher than $8.5 \mathrm{MPa}$, the saturated salt solutions method was used and a new oedometer using this suction control technique was developed. For suctions lower than $8.5 \mathrm{MPa}$ an osmotic oedometer was used. Despite the differences between the applied suction components (matric and total), the correlation between the two methods was verified for the tested material. The second part of the paper presents a set of oedometer tests conducted under various suctions. The effect of the applied suction on the hydromechanical parameters was studied. First, two swelling phases were highlighted: a low swelling phase above a suction of $4 \mathrm{MPa}$ and a high swelling one below this value. These phases were considered as being related to the microstructure of compacted swelling clays. Secondly, it was shown that the slopes of the elastic part and of the plastic part of the consolidation curves were not influenced significantly by the applied suctions. In opposition, the preconsolidation pressure is affected by the decrease of the applied suctions even in the low swelling phase. Such a behaviour could be explained by the effects of wetting on the microstructure.

Keywords: Expansive Soil; Suction; Compacted Soil; Hydromechanical behaviour; Compressibility; Laboratory Tests. 


\section{INTRODUCTION}

Because of their very low permeability, compacted swelling soils are used for the construction of engineered barriers in waste disposal facilities. During their lifetime, these materials undergo wetting/drying cycles, i.e. suction variations. These soils exhibit large volume variations in response to suction changes. However, the relationship between suction variations and compressibility is not well known as far as compacted swelling materials are concerned. The experimental investigation of the hydromechanical behaviour of unsaturated swelling soils requires the use of suction controlled devices in a comprehensive range of suction, from low to very high suctions. However there are very few suction controlled studies performed over an extensive range of suction in the literature (Bernier et al., 1997; Al Mukthar et al. 1999; Villar, 1999; Alonso et al., 2001; Cui et al. 2002). This is mainly related to the fact that the methods commonly used in experimental testing, such as the air overpressure method (Richards, 1935) and the osmotic method (Kassif \& Ben Shalom, 1971) investigate only a small suction range, from saturation up to a few MPa (Fig. 1). Some developments of these methods have been used, but the maximum suction they are able to reach is about 14 MPa (Villar, 1995; Delage et al., 1998). The only available method to reach several hundred MPa is the control of relative humidity by means of salt solutions. However, this is a complex method to implement because of some uncertainties on the imposed suction due to temperature and pressure variations, and the measurement of the exact value of the relative humidity inside the testing device (Delage et al., 1998; Cuisinier, 2002).

This paper presents a study of the hydromechanical behaviour of a compacted swelling soil carried out on a range of suction comprised between 0 and $40 \mathrm{MPa}$. In the first part, oedometers using the osmotic method and others based on the saturated salt solutions technique are introduced. The feasibility of these devices and the correlation between the two suction control methods is also discussed. In the second part, a set of suction controlled 
oedometer tests is presented. From these results, the influence of suction on the swelling potential $\Delta \mathrm{H} / \mathrm{H}$, the preconsolidation pressure $\mathrm{p}_{0}(\mathrm{~s})$, the slopes of the elastic part $\kappa$, and of the plastic part $\lambda(\mathrm{s})$, of the consolidation curves is discussed.

The results are considered with two independent variables: the net vertical stress $\sigma_{\mathrm{v}}{ }^{*}$, defined as the difference between the total vertical stress and the pore-air pressure, and the suction s, which corresponds to the difference between the pore-air pressure and the pore-water pressure (Coleman, 1962; Matyas \& Radhakrishna, 1968).

\section{DESCRIPTION OF THE SUCTION CONTROLLED OEDOMETER DEVICES}

Figure 1 shows that at least two complementary suction control techniques are required to perform a study over an extensive suction range. The salt solutions technique for suctions higher than 8.5 MPa and the osmotic method for suctions lower than this value were selected.

\subsection{Salt solutions method}

The basic principle of the saturated salt solutions technique is to introduce a sample inside a hermetic chamber where the relative humidity is maintained constant with a salt solution. The water exchange occurs by vapour transfer. The relative humidity $\mathrm{Hr}(\%)$ is linked to the suction, through Kelvin's law:

$\mathrm{s}=\gamma_{\mathrm{w}} \frac{\mathrm{R} \mathrm{T}}{\mathrm{Mg}} \ln (\mathrm{Hr})$

with $\mathrm{R}=$ universal gas constant $\left(8.31 \mathrm{~J} \cdot \mathrm{mol}^{-1} \cdot \mathrm{K}^{-1}\right) ; \gamma_{\mathrm{w}}=$ unit weight of water $\left(9.81 \mathrm{kN} \cdot \mathrm{m}^{-3}\right)$; g = gravitational constant $\left(9.81 \mathrm{~m} \cdot \mathrm{s}^{-2}\right) ; \mathrm{M}=$ molecular weight of water $\left(1810^{-3} \mathrm{~kg} \cdot \mathrm{mol}^{-1}\right) ; \mathrm{T}=$ absolute temperature $(\mathrm{K})$. It was possible to apply different suctions with this method, depending on the kind of salt solution used and its concentration. In this study, totally saturated salt solutions were selected. 
The value of the relative humidity imposed by a given salt is highly dependent on temperature (AFNOR, 1999). In our tests, the room temperature was maintained at $20 \pm 0.15{ }^{\circ} \mathrm{C}$. The relative humidity imposed by a given saturated salt solution is known with an uncertainty comprised between 1 and $2 \%$ (AFNOR, 1999). Delage et al. (1998) and Cuisinier \& Masrouri (2001) have demonstrated that these uncertainties limit the use of saturated salt solutions to suctions higher than $8.5 \mathrm{MPa}$, because below this value the relative uncertainty on the imposed suction is higher than $15 \%$.

Given thermodynamic considerations, the soil suction is the sum of several components; a matric potential (adsorption and capillary), an osmotic potential (related to solute concentrations), and other components (related to pressure and temperature) which are supposed as being of negligible importance here. A comprehensive review of these considerations is available in Fredlund \& Rahardjo (1993). With the saturated salt solutions method, total suction is imposed during a test.

The new odometer device using saturated salt solutions is shown in Figure 2. This device combines, in the same system, the functions of a basic oedometer (AFNOR, 1997) and of a closed chamber with constant relative humidity (ISO 483, 1998). Based on this principle, two different devices, with two maximum vertical pressures (1 200 and $20000 \mathrm{kPa}$ ) were developed. The range of suction that could be attained was comprised between 8.5 and 292.4 MPa. The diameter of the sample was $7.4 \mathrm{~cm}$ in the low vertical stress oedometer and $5 \mathrm{~cm}$ in the other one. In both cases, the initial height of the sample was about $1 \mathrm{~cm}$. The different elements of the device in contact with the sample were made of porous steel in order to facilitate the vapour transfer between the sample and the saturated salt solution. Following a change of the applied suction and/or the vertical stress, several weeks are required to reach deformation equilibrium (Cuisinier \& Masrouri, 2003). Therefore, one test might take several 
months to be completed. The validation of the efficiency of these new oedometers was presented in Cuisinier \& Masrouri (2002).

\subsection{Osmotic method}

In this method, a semi-permeable membrane, is introduced between a solution of macromolecules and an unsaturated soil sample (Zur, 1966). The exchange of water is due to the process of osmosis. The amount of exchanged water, and therefore the suction, is controlled by the macromolecule concentration: the higher the concentration, the higher the suction. The macromolecule commonly in use is the polyethyleneglycol (PEG) with a molecular weight of 20000 or $6000 \mathrm{Da}^{1}$. The relationship between PEG concentration and suction (Fig. 3) is known for suctions ranging from 0 to $1.5 \mathrm{MPa}$ and is independent of the PEG molecular weight (Williams \& Shaykewich, 1969). In this range, Cui (1993) has proposed an empirical calibration relationship between PEG concentration and suction:

$\mathrm{s}=11 \mathrm{c}^{2}$

where $\mathrm{s}$ is the suction in MPa and $\mathrm{c}$ the concentration of the PEG solution expressed in $\mathrm{g}$ of PEG per g of water. This equation is also reproduced in Figure 3. The temperature influences the relationship between PEG concentration and suction (Guiras-Skandaji, 1996). In order to limit this effect, the temperature was maintained at $20 \pm 1.5^{\circ} \mathrm{C}$.

With the osmotic suction control method, only the matric suction component of a sample is mastered during a test.

It was necessary to calibrate the PEG solution from a suction of 1.5 MPa up to 8.5 MPa. For such a calibration, a sample of PEG solution, prepared at a known concentration, is enclosed in a hermetic chamber where the relative humidity is kept constant by a saturated salt solution. Delage et al. (1998) have performed such tests and their results, obtained with PEG

\footnotetext{
${ }^{1} 1$ Dalton $(\mathrm{Da})=1.6605 .10^{-24} \mathrm{~g}$.
} 
6000 , are plotted in Figure 3. An additional calibration test was made with a similar procedure using PEG 6000 for a suction of $8.5 \mathrm{MPa}$. The final concentration of the PEG solution was $0.879 \mathrm{~g}$ of PEG per g of water. The result of this test was in good agreement with existing data and the empirical relationship. The osmotic method could therefore be used up to $8.5 \mathrm{MPa}$.

A schematic representation of an osmotic oedometer is presented in Figure 4 (Kassif \& Ben Shalom, 1971). A pump allows to circulate a solution of macromolecules (PEG), at a given concentration. The solution passes through the grooved base of the oedometer, which was designed to allow fluid to circulate through the whole bottom surface of the sample. Between the sample and the PEG solution a semi-permeable membrane (Spectra/Por ${ }^{\circledR} n^{\circ} 4$ ) was introduced to prevent PEG macromolecules from passing toward the sample. In our device, the maximum vertical pressure accessible was $1800 \mathrm{kPa}$. The range of suction was comprised between 0 and $8.5 \mathrm{MPa}$. The deformability of the semi-permeable membrane and the overall device was evaluated. The evaporation through the upper face of the sample was minimized by positioning a plastic film all around the oedometer. The diameter of the sample was $7 \mathrm{~cm}$ and its initial height was about $1 \mathrm{~cm}$. When a given suction was applied, approximately ten days were required for a deformation equilibrium to be reached. The mechanical loading was made in the same manner as in a typical oedometer test, and approximately 2 days were needed to reach a deformation equilibrium for a given stress step (Cuisinier, 2002).

\section{MATERIAL AND SAMPLE PREPARATION}

The study was conducted with an artificially prepared mixture (40\% of silt and $60 \%$ of bentonite). The mineralogical composition of the materials was determined by $\mathrm{X}$ ray diffractometry. The silt contained $60 \%$ quartz, $20 \%$ montmorillonite, $11 \%$ feldspar, and the 
remaining part was made up of kaolinite and mica. The bentonite was composed of more than $90 \%$ of calcium montmorillonite. The main physical properties of the materials and of the mixture are shown in Table 1.

The size of the particles used to prepare the samples was less than $400 \mu \mathrm{m}$ (obtained by sieving). The materials were mixed together and wetted up to a gravimetric water content of $15 \%$ (dry side of optimum). Then the mixture was statically compacted under a vertical pressure of $1000 \mathrm{kPa}$. This low gravimetric water content, close to the shrinkage limit, was selected in order to prevent the shrinkage of the sample when very high suctions were imposed. It was not possible to prepare samples at a gravimetric water content lower than $15 \%$ as they would not have been sufficiently cohesive to be handled.

Under these conditions, the initial dry unit weight of the samples was about $12.7 \mathrm{kN} . \mathrm{m}^{-3}$. The initial matric suction, measured by the Filter Paper Method (ASTM, 1995a), was comprised between 20 and $25 \mathrm{MPa}$ and the osmotic suction was comprised between 1 and $2 \mathrm{MPa}$. The swelling potential $\Delta \mathrm{H} / \mathrm{H}$ when a sample is fully saturated, and the swelling pressure $\mathrm{P}_{\mathrm{s}}$, required to eliminate height variations during wetting, measured by the free swelling method (ASTM, 1995b), were respectively $19 \%$ and $250 \mathrm{kPa}$. The gravimetric water content determined after full saturation inside an oedometer was $49 \%$.

\section{STUDY OF HYDROMECHANICAL BEHAVIOUR FROM LOW TO VERY HIGH}

\section{SUCTIONS}

In the remaining part of the paper, the tests are referenced in order to identify the type of suction control method: $\mathrm{O}$ for osmotic and $\mathrm{S}$ for saturated salt solutions. The subsequent letters indicate qualitatively the stress paths followed: W for wetting phase, D for drying phase and L for the loading/unloading phase. 


\subsection{Test program}

The stress paths followed are plotted in Figure 5. All the tests began at point "A" under a low vertical pressure of about $10 \mathrm{kPa}$, and an initial suction of about 20/25 MPa. During the first phase, a different suction was applied in several steps for each test. In the second phase the samples were loaded in several steps and then unloaded under constant suction. The test OWL4 is not represented in Figure 5 as the applied suction was $0 \mathrm{MPa}$ in this test.

\subsection{Correlation between two suction control methods}

As these two methods do not impose the same suction components, the correlation between the results obtained with them was checked. Two tests were conducted: OWL1 in the osmotic oedometer and SWL1 in the saturated salt solutions oedometer. In both tests, the same stress paths were followed. These paths began by a wetting from the initial suction to a suction of 8.5 $\mathrm{MPa}$ under a low vertical pressure $(10 \mathrm{kPa})$. Following equilibrium under a constant suction, the samples were loaded in several steps and then unloaded (Fig. 6). The swelling potential $\Delta \mathrm{H} / \mathrm{H}$ registered at the end of the wetting phase, the slope of the consolidation curves $\kappa$, the slope of the virgin compression line $\lambda(s)$, and the preconsolidation pressure $\mathrm{p}_{0}(\mathrm{~s})$, were determined and summarized in Table 2. In the same table, the initial and final gravimetric water contents of the samples $\mathrm{w}_{\mathrm{i}}$ and $\mathrm{w}_{\mathrm{f}}$, are given. As is shown in Figure 6 and in Table $2, \lambda(s)$ and $\kappa$ are not significantly affected by the suction control method contrary to $\mathrm{p}_{0}(\mathrm{~s})$, which is $80 \mathrm{kPa}$ lower for the test performed in the osmotic oedometer. The swelling potential and the final water content are both higher in the test performed in the osmotic oedometer.

The prepared samples contained a certain amount of dissolved salts. Olsen (1985) has demonstrated that, when exposed to distilled water, the dissolved salts contained inside a soil sample tend to diffuse outwards of the sample, and the water inward of the sample. This 
phenomenon occurred in our osmotic tests as the semi-permeable membrane is permeable to water and solutes. In fact, during a test in the osmotic oedometer, a certain amount of water exchange is controlled by the PEG concentration, but an additional amount of water enters the soil sample because of this solute gradient. This could explain the higher water content and swelling potential $\Delta \mathrm{H} / \mathrm{H}$ in test OWL1 than in test SWL1 where such a phenomenon was not possible. The larger $\Delta \mathrm{H} / \mathrm{H}$ in test OWL1 than in test SWL1 tend to soften the soil structure and consequently, $\mathrm{p}_{0}(\mathrm{~s})$ is low in test OWL1. On the other hand, small variations in the calibration of osmotic suction applied by PEG solution or the uncertainty associated to suction imposed by salt solutions may explain the small differences observed in both tests. The effect of suction components on the compressibility parameters, $\lambda(s)$ and $\kappa$, is not significant in our tests. This could be explained by the nature of the clay used. During the vertical loading stage, the salt concentration is probably higher in sample SWL1 than in sample OWL1. Olson \& Mesri (1970) have also shown that the salt concentration slightly affects the compressibility parameters, $\lambda(\mathrm{s})$ and $\kappa$ of calcium montmorillonite.

These tests demonstrate that the influence of the osmotic component of suction is not significant for a suction of $8.5 \mathrm{MPa}$, under which the correlation between both suction control techniques is checked for this material.

\subsection{Hydromechanical behaviour from low to high suctions}

Figure 7 depicts the relationship between the void ratio and the net vertical stress for all the tests. The hydromechanical parameters determined from these curves are presented in Table 2. The parameters $\lambda(\mathrm{s})$ and $\kappa$ are plotted in Figure 8 . It seems that the parameter $\kappa$ was not significantly affected by the applied suction in opposition to the parameter $\lambda(\mathrm{s})$. These observations are similar to other data available in the literature (e.g. Alonso et al., 1987). Figure 9 compares the variation of $\mathrm{p}_{0}(\mathrm{~s})$ and $\Delta \mathrm{H} / \mathrm{H}$ after wetting at the applied suctions. First, it can be seen that the volume of the sample did not decrease significantly when a suction 
higher than the initial suction was applied (test SDL1 - $40 \mathrm{MPa}$ ). During wetting two swelling phases were highlighted: a low swelling phase above $4 \mathrm{MPa}$ and a high swelling phase below this value. It is well known that the swelling of clays occurs in several steps (Kassif \& Ben Shalom, 1971; Komine \& Ogata, 1996). The first step corresponds to the initial hydration of clays with the insertion of between the unit clay layer. This could explain the low swelling phase: the clay particles fill the initial voids of the sample. The high swelling phase started when the major part of the macropores of the sample were already filled by the expanded clay particles.

Figure 9 demonstrates that $\mathrm{p}_{0}(\mathrm{~s})$ decreased continuously from 40 down to $0 \mathrm{MPa}$. A basic assumption is to link this parameter to the density of the sample: the lower the density, the lower the preconsolidation pressure. But this interpretation is not sufficiently satisfactory to explain such a sharp decrease of preconsolidation pressure. A possible explanation could be the void filling by the clay particles in the low swelling phase. In fact, during the first stage of wetting, the macrostructural density is not changed significantly, but the microstructure of the sample is altered dramatically, decreasing the mechanical properties of the studied material. However, further microstructural investigations are required before a conclusion can be arrived at on this point. It will also enable the influence of the montmorillonite swelling to be determined more precisely.

\section{CONCLUSION}

Two kinds of suction controlled oedometers, one with saturated salt solutions technique (control of total suction) and the other with the osmotic method (control of matric suction) were used in this study. The correlation between the two methods was checked. It was found 
that, for the studied soil, the methods used did not significantly affect the values of the hydromechanical parameters determined.

The swelling upon wetting was studied as a function of the applied suction. Two swelling phases have been highlighted: a low swelling phase for suctions higher than $4 \mathrm{MPa}$ and a high swelling phase below $4 \mathrm{MPa}$. The preconsolidation pressure is strongly affected by the suction decrease between the initial suction and $4 \mathrm{MPa}$, that is to say during the low swelling phase. This demonstrates that the preconsolidation pressure of a compacted swelling soil is not only a function of its density but it depends also on the microscopic repartition of the clay particles inside the soil.

Our results highlight the extreme sensitivity of the hydromechanical behaviour of a compacted swelling soil to any variation in suction, even in the range of very high suctions. 


\section{REFERENCES}

AFNOR XP P 94-090-1, 1997. Essai œdométrique. Géotechnique. tome 1: essais en laboratoire. Association Française de Normalisation, Paris, 21 p.

AFNOR NF X 15-119, 1999. Mesure de l'humidité de l'air - Générateurs d'air humide à solutions salines pour l'étalonnage des hygromètres. Association Française de Normalisation, Paris, 22 p.

Al-Mukhtar, M., Qi, Y., Alcover, J.F., Bergaya, F., 1999. Oedometric and water retention behavior of highly compacted unsaturated smectites. Canadian Geotechnical Journal 36, 675-684.

Alonso, E.E., Gens, A., Hight, D.W., 1987. Special problem soils. General report. Proc. of the $9^{\text {th }}$ European Conf. on Soil Mechanics and Foundation Engineering, 5.1-5.60.

Alonso, E. E., Romero, E., Hoffmann, C., García-Escudero, E., 2001. Expansive bentonite/sand mixtures in cyclic controlled-suction drying and wetting. Proc. $6^{\text {th }}$ Int. Workshop on Waste Isolation Research, École Nationale des Ponts et Chaussées, Paris, 513-541.

ASTM D 5298 - 94, 1995a. Standard test method for measurement of soil potential (suction) using filter paper, Vol. 4.09, 154-159.

ASTM D 4546 - 90, 1995b. One-dimensional swell or settlement potential of cohesive soils. Vol. 4.08, 693-699.

Bernier, F., Volckaert, G., Alonso, E. E. , Villar, M., 1997. Suction controlled experiments on Boom clay. Engineering Geology 47, 325-338.

Coleman, J.D., 1962. Stress-strain relations for partly saturated soils. Géotechnique 12, 348350.

Cui, Y. J., 1993. Étude du comportement d'un limon compacté non saturé et de sa 
modélisation dans un cadre élastoplastique. Thèse de doctorat de l’École Nationale des Ponts et Chaussées, Paris, 280 p.

Cui Y. J., Yahia-Aissa M., Delage P., 2002. A model for the volume change behavior of heavily compacted swelling clays, Engineering Geology 64, 233-250.

Cuisinier, O, 2002. Comportement hydromécanique des sols gonflants compactés. PhD thesis, Institut National Polytechnique de Lorraine, Nancy, France, 165 p.

Cuisinier, O., Masrouri, F., 2001. Développement d’un appareil œdométrique à succion contrôlée pour l'étude des sols gonflants. XV ${ }^{\text {ème }}$ Congrès Français de Mécanique, Nancy, réf. 128.

Cuisinier, O., Masrouri, F., 2002. Study of the hydromechanical behaviour of a swelling soil under high suctions. $3^{\text {rd }}$ International Conference on Unsaturated Soils, Balkema, Recife, vol. 2, 587-592.

Cuisinier O., Masrouri F., 2003, Comportement hydromécanique d'un sol gonflant sous très fortes succions, Comptes Rendus Mécanique 331, 203-210.

Delage, P., Howat, M. D., Cui, Y. J., 1998. The relationship between suction and the swelling properties in a heavily compacted swelling clay. Engineering Geology 50, 31-48.

Fredlund, D. G., Rahardjo, H., 1993. Soils mechanics for unsaturated soils. John Wiley \& Sons (New York.), 517 p.

Guiras-Skandaji, H., 1996. Déformabilité des sols argileux non saturés : etude expérimentale et modélisation. PhD Thesis, Institut National Polytechnique de Lorraine, Nancy, France, 300 p.

ISO 483: 1998. Plastics - Small enclosures for conditioning and testing using aqueous solutions to maintain relative humidity at constant value. International Organization for Standardization, Geneva.

Kassif, G., Ben Shalom, A., 1971. Experimental relationship between swell pressure and 
suction. Géotechnique 21, 245-255.

Komine, H., Ogata, N., 1996. Prediction for swelling characteristics of compacted bentonite. Canadian Geotechnical Journal 33, 11-22.

Matyas, E.L., Radhakrishna, H.S.. 1968. Volume change characteristics of partially saturated soils. Géotechnique 18, 432-448.

Olsen, H. W., 1985. Osmosis: a cause of apparent deviations from Darcy’s law. Canadian Geotechnical Journal 22, 238-241.

Olson, R. E., Mesri, G., 1970. Mechanisms controlling compressibility of clays. Journal of Soil Mechanics Foundations Division ASCE 96, 1863-1878.

Richards, L. A., 1935. Capillary conduction of liquids through porous medium. Physics 1, 318-333.

Villar, M. V., 1995. First results of suction controlled oedometer tests in highly expansive montmorillonite. Proc. $1^{\text {st }}$ Int. Conf. on Unsaturated Soils, Paris, vol. 1, 207-213.

Villar, M. V., 1999. Investigation of the behaviour of bentonite by means of suctioncontrolled oedometer tests. Engineering Geology 54, 67-73.

Villar, M. V., Martín, P. L., 1996. Suction-controlled oedometer tests in montmorillonite clay: preliminary results. Engineering Geology of Waste Disposal, Geological Society Engineering Geology, Special Publication 11, 309-312.

Williams, J., Shaykewich, C. F., 1969. An evaluation of polyethyleneglycol (PEG) 6000 and PEG 20000 in the osmotic control of soil water matric potential. Canadian Journal of Soil Science 49, 397-401.

Zur, B., 1966. Osmotic control of the matric soil-water potential: I. Soil water system. Soil Science 102, 394-398. 


\section{TABLES}

\section{Table 1}

Characteristics of the studied materials.

$\begin{array}{ccccc}\text { Material } & \mathrm{w}_{\mathrm{L}} & \mathrm{w}_{\mathrm{P}} & \mathrm{Ip} & \gamma_{\mathrm{s}} \\ & \% & \% & \% & \mathrm{kN} . \mathrm{m}^{-3} \\ \text { Silt } & 53 & 30 & 23 & 26.7 \\ \text { Bentonite } & 164 & 64 & 100 & 27.0 \\ \text { Mixture } & 87 & 66 & 21 & 26.9\end{array}$


Table 2

Hydromechanical parameters from s $=0$ to $40.0 \mathrm{MPa}$.

[O: osmotic; S: saturated salt solutions; W: wetting; D: drying; L: loading]

\begin{tabular}{|c|c|c|c|c|c|c|c|c|}
\hline Test & Stress & Suction under & $\mathrm{W}_{\mathrm{i}}$ & $\mathrm{W}_{\mathrm{f}}$ & $\Delta \mathrm{H} / \mathrm{H}$ & $\kappa$ & $\lambda(\mathrm{s})$ & $\mathrm{p}_{0}(\mathrm{~s})$ \\
\hline \multirow[t]{3}{*}{ number } & paths & which sample & $(\%)$ & (\%) & $(\%)$ & & & $(\mathrm{kPa})$ \\
\hline & (Fig. 6) & is loaded* & & & & & & \\
\hline & & (MPa) & & & & & & \\
\hline SDL1 & A-I-J-I & 39.7 & 14.9 & 12.4 & -0.2 & 0.02 & 0.26 & 1090 \\
\hline SL & A-B-A & 20.8 & 14.9 & 15.1 & 0 & 0.03 & 0.28 & 1000 \\
\hline SWL1 & A-C-D-C & 8.5 & 15.0 & 16.8 & 0.5 & 0.03 & 0.31 & 450 \\
\hline SWL2 & A-C-D-C & 8.5 & 15.0 & 17.0 & 0.5 & 0.03 & 0.30 & 490 \\
\hline OWL1 & A-C-D-C & 8.5 & 14.7 & 17.7 & 1.2 & 0.03 & 0.29 & 370 \\
\hline OWL2 & A-C-E-F-E & 4 & 14.5 & 20.7 & 2.8 & 0.03 & 0.30 & 200 \\
\hline OWL3 & A-G-H-G & 1.2 & 14.9 & 26.4 & 11.6 & 0.03 & 0.23 & 65 \\
\hline OWL4 & / & 0 & 14.7 & 42.0 & 16.2 & 0.05 & 0.22 & 50 \\
\hline
\end{tabular}




\section{FIGURE CAPTIONS}

Figure 1. Range of suction of the main suction control techniques.

Figure 2. Schematic of the suction controlled oedometer device using saturated salt solutions.

Figure 3. Calibration curve between suction and PEG concentration.

Figure 4. Schematic of the suction controlled oedometer device using osmotic solutions.

Figure 5. Stress paths followed.

Figure 6. Correlation between the two suction control techniques.

Figure 7. Results of the different suction controlled oedometer tests.

Figure 8. Parameters $\kappa$ and $\lambda(\mathrm{s})$ as a function of the applied suction during mechanical loading (white signs: salt solutions technique; black signs: osmotic technique).

Figure 9. Percent heave $(\Delta \mathrm{H} / \mathrm{H})$ after wetting to a given suction and preconsolidation pressure $\mathrm{p}_{0}(\mathrm{~s})$ as a function of the suction applied during mechanical loading (white signs: salt solutions technique; black signs: osmotic technique). 
FIGURES

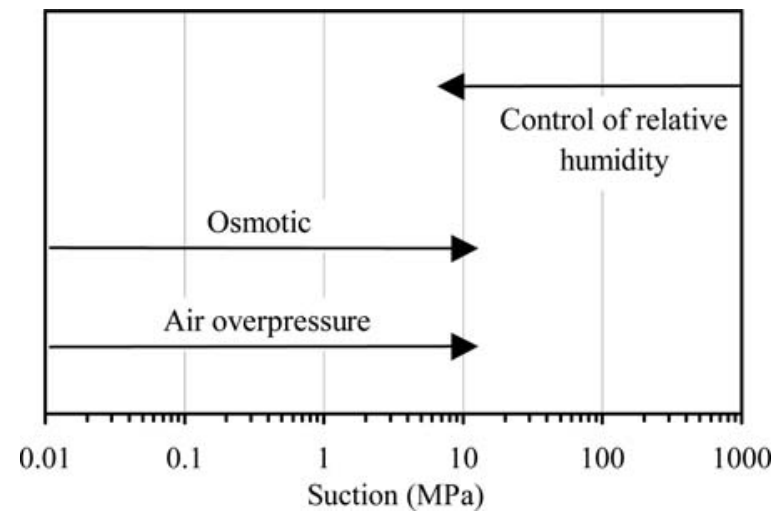

\section{Figure 1}

Range of suction of the main suction control techniques.

Cuisinier and Masrouri 


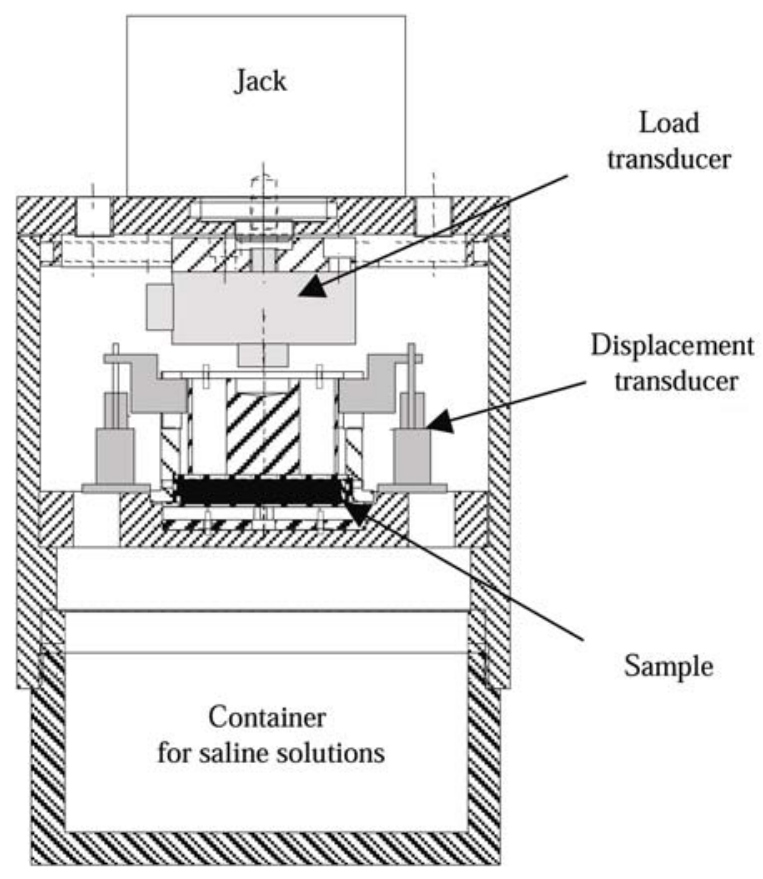

\section{Figure 2}

Schematic of the suction controlled oedometer device using saturated saline solutions (Cuisinier 2002).

\section{Cuisinier and Masrouri}




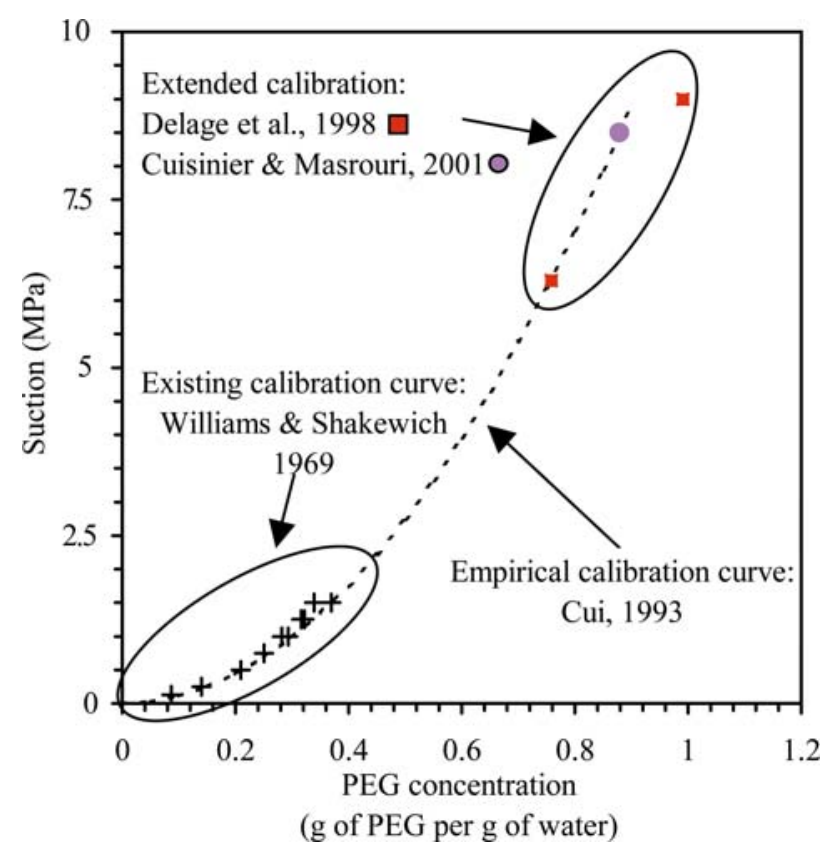

Figure 3

Calibration curve between suction and PEG concentration.

Cuisinier and Masrouri 


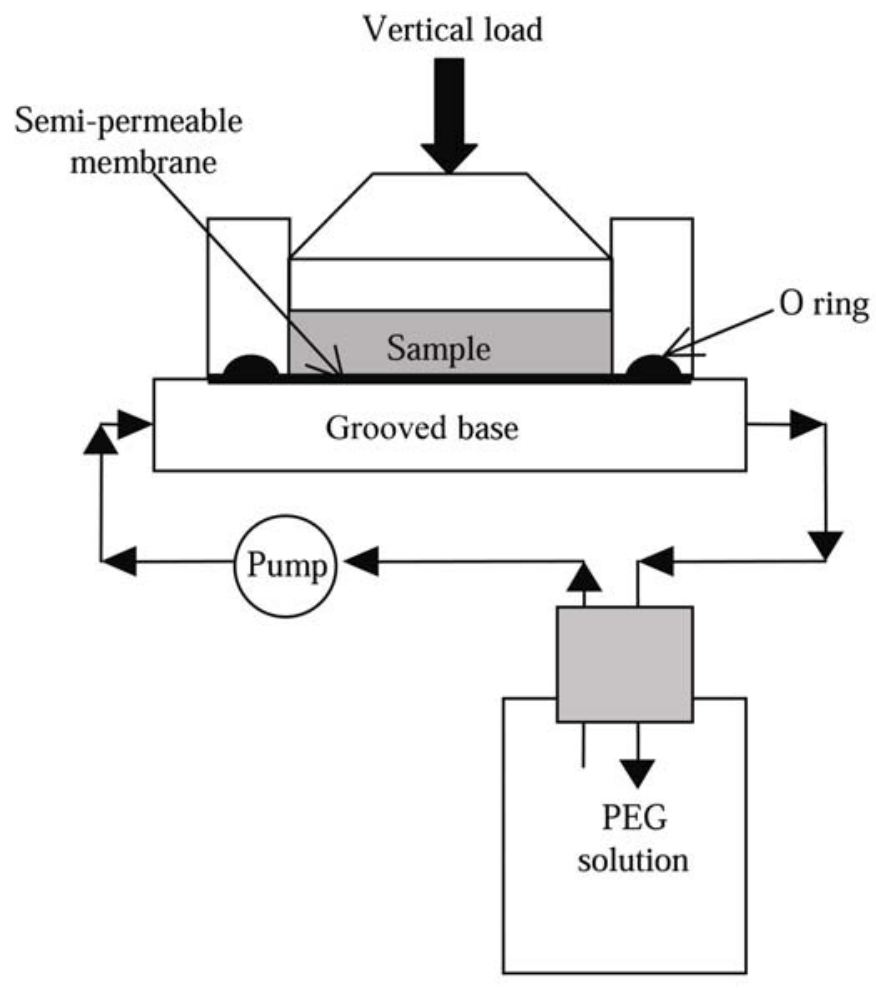

Figure 4

Schematic of the suction controlled oedometer device using osmotic solutions.

Cuisinier and Masrouri 
SDL1 : A-I-J-I SL : A-B-A

SWL1 OWL2: A-C-E-F-E

SWL2 A-C-D-C OWL3 : A-C-E-G-H-G

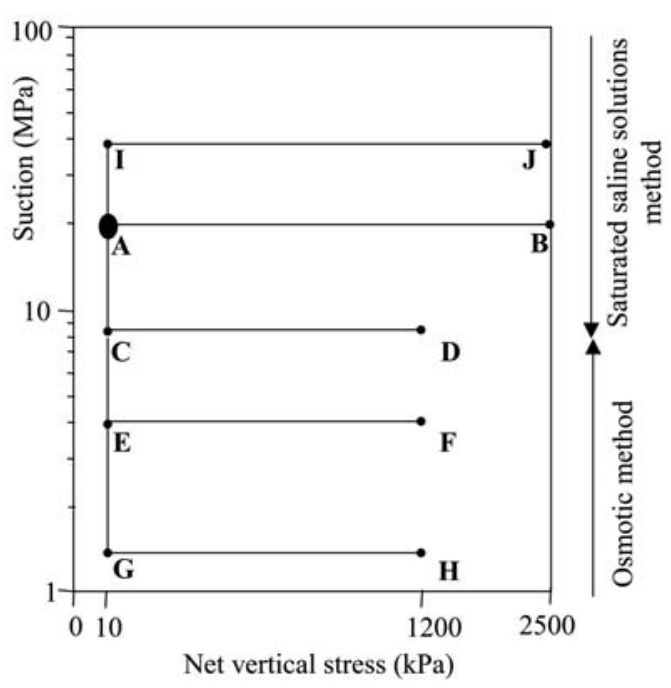

Figure 5

Stress paths followed.

Cuisinier and Masrouri 


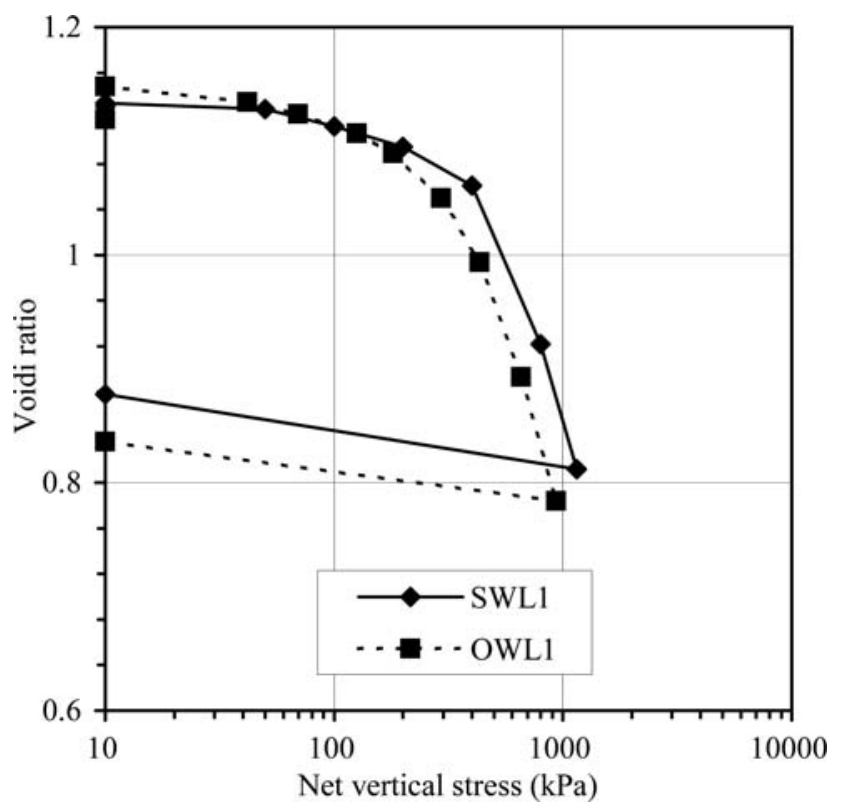

Figure 6

Correlation between the two suction control techniques.

Cuisinier and Masrouri 


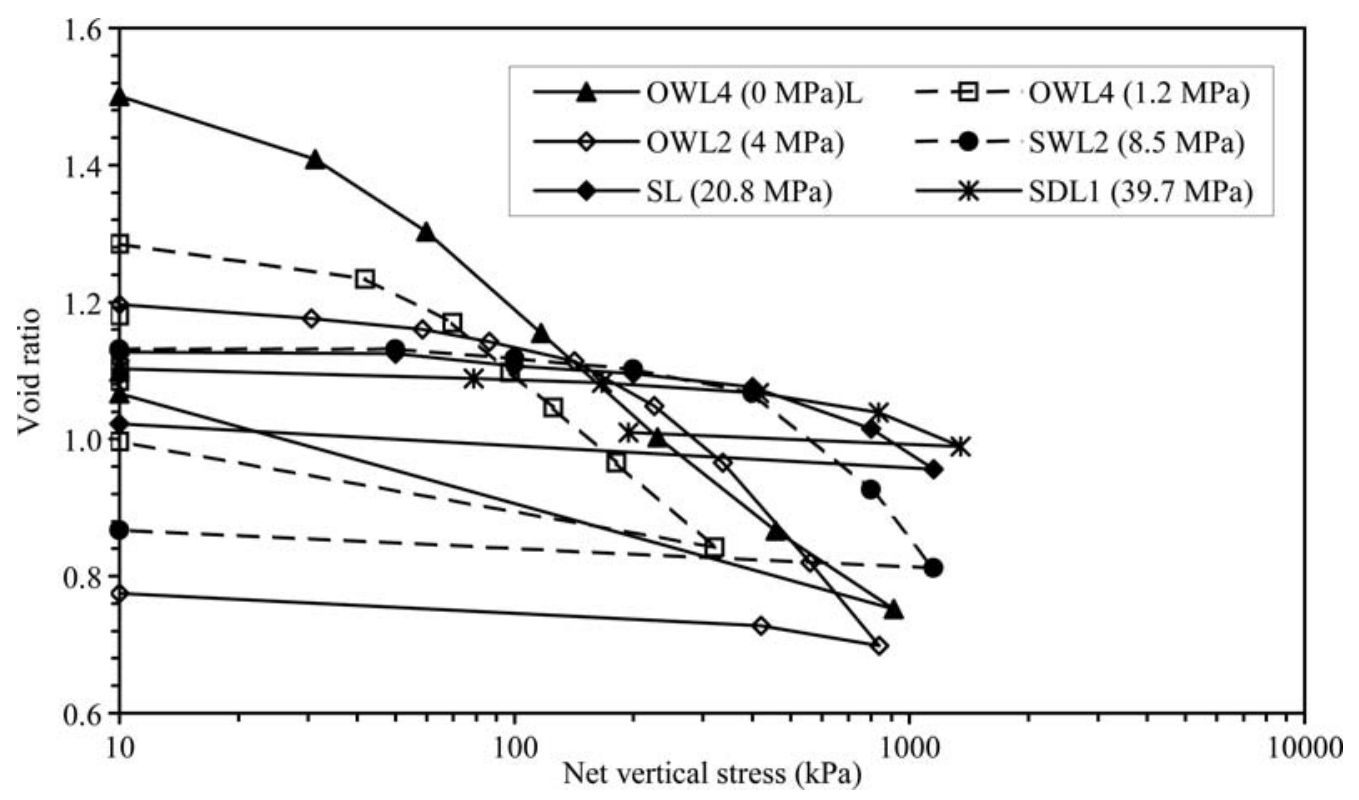

Figure 7

Results of the different suction controlled oedometer tests.

Cuisinier and Masrouri 


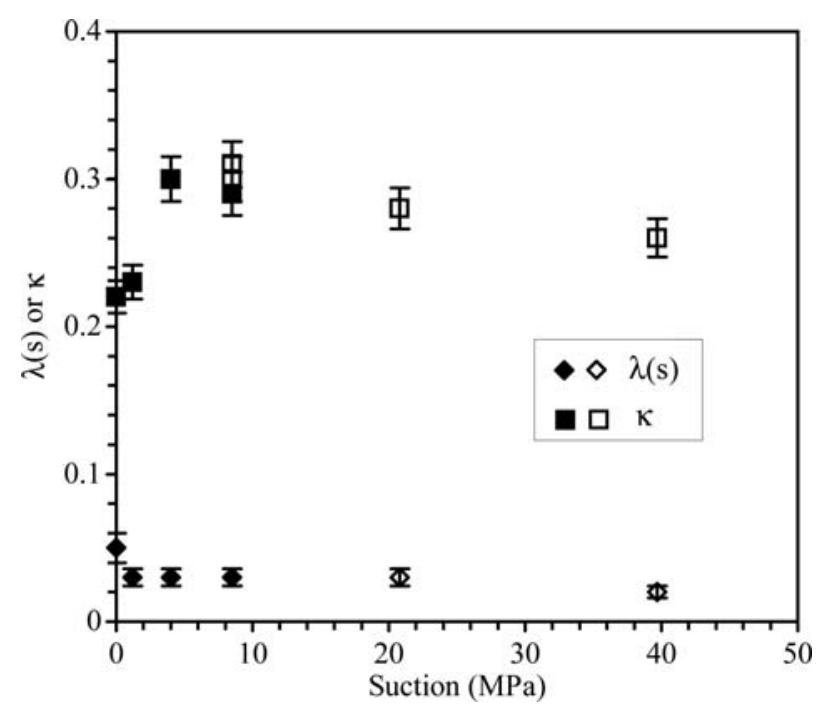

Figure 8

Parameters $\kappa$ and $\lambda(\mathrm{s})$ as a function of the applied suction during mechanical loading (white signs: salt solutions technique; black signs: osmotic technique).

Cuisinier and Masrouri 


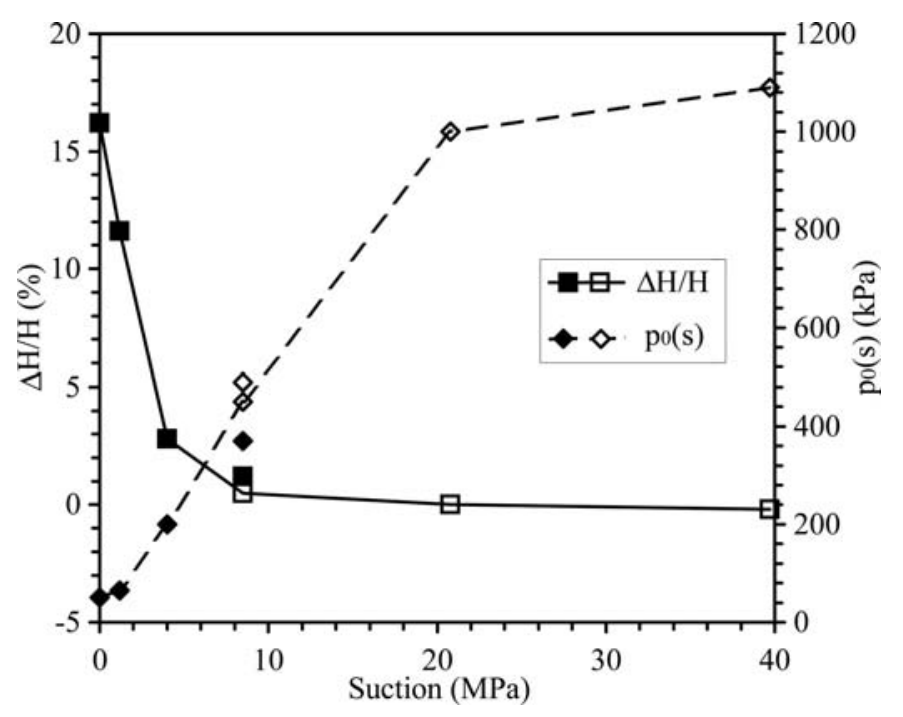

Figure 9

Percent heave $(\Delta \mathrm{H} / \mathrm{H})$ after wetting to a given suction and preconsolidation pressure $\mathrm{p}_{0}(\mathrm{~s})$ as a function of the suction applied during mechanical loading (white signs: salt solutions technique; black signs: osmotic technique).

Cuisinier and Masrouri 